\title{
PROSIDINE
}

\section{ISSN $1411-9005$}

Seri Filsafat Teologi Widya Sasana
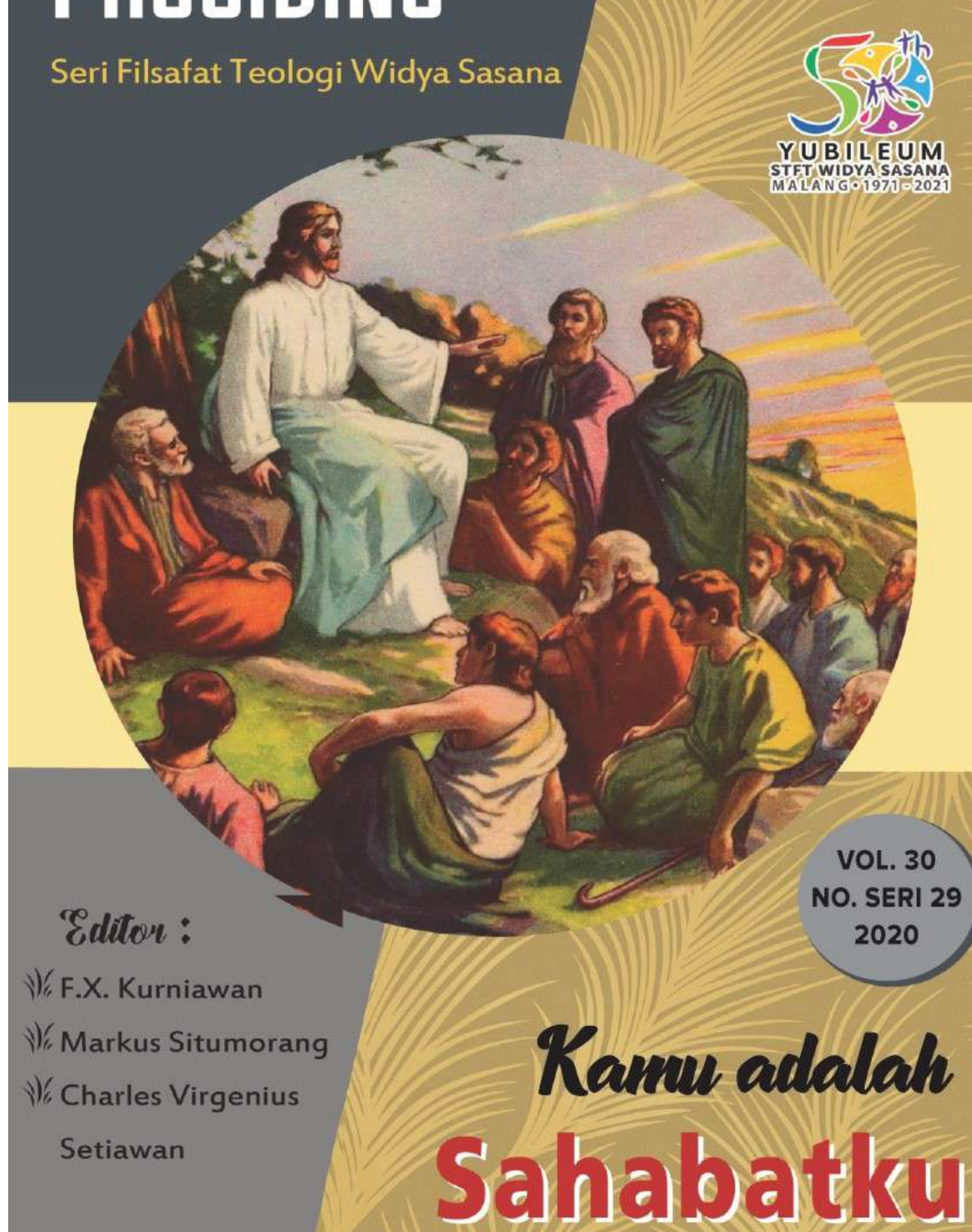
Seri Filsafat Teologi Widya Sasana ISSN 1411 - 9005

\title{
KAMU \\ ADALAH SAHABATKU
}

\author{
Editor: \\ F.X. Kurniawan \\ Markus Situmorang \\ Charles Virgenius Setiawan
}

STFT Widya Sasana

Malang 2020 


\section{KAMU ADALAH SAHABATKU}

STFT Widya Sasana

J1. Terusan Rajabasa 2

Malang 65146

Tlp. (0341) 552120; Fax (0341) 566676

E-mail: stftws@gmail.com

Website: www.stfwidyasasana.ac.id; www.stftws.org

ISSN: 1411-9005 


\section{DAFTAR ISI}

\section{SERI FILSAFAT TEOLOGI WIDYA SASANA \\ VOL. 30, NO. SERI NO. 29, TAHUN 2020}

Pengantar

Tim Editor ......................................................................... i

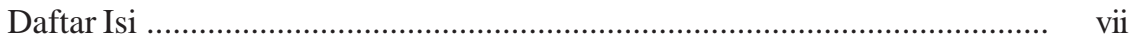

\section{PEMIKIRANDARI PERSPEKTIF FILOSOFIS}

Persahabatan Merespon Tanda-tanda Zaman

(Analis Historiografis Duc in Altum Kolaborasi STFT Widya Sasana)

F.X. Armada Riyanto

Makna Persahabatan Sebuah Tinjauan dari Perspektif Filsafat

J. Sudarminta

Membangun Identitas Inklusif

Krisis Identitas dalam Lensa Kajian Poskolonialisme

Robertus Wijanarko

Menyoal Persahabatan sebagai Problem Relasionalitas:

Sebuah Konstruksi atas Konsep Alteritas Emmanuel Levinas

dan Pluralitas Hannah Arendt

Pius Pandor

Persahabatan dalam Prespektif Neo-Thomisme Yoseph Pieper Donatus Sermada

Konsep Persahabatan dalam Pemikiran Thomas Aquinas

Valentinus Saeng

Humanisme Bagi Sesama - Menyingkap Akar Kekerasan

dalam Relasi Antarmanusia dan Etika Tanggungjawab Menurut

Emmanuel Levinas

Editha Soebagio 


\section{PEMIKIRANDARIPERSPEKTIF BIBLIS}

Persahabatan antara Allah dan Manusia:

Suatu Tinjauan Alkitabiah

Henricus Pidyarto Gunawan ........................................................... 161

Abraham Sahabat Allah

Berthold Anton Pareira

Sahabat-Sahabat Tuhan Yesus: Suatu Renungan Teologi Biblis

Berthold Anton Pareira

Doa Batin:

Doa Persahabatan dengan Yesus Menurut Santa Teresia Dari Yesus

Berthold Anton Pareira

Redefinisi Arti Sahabat dalam Perspektif Kitab Ayub

Gregorius Tri Wardoyo

Dinamika Persahabatan Barnabas dan Paulus

F.X. Didik Bagiyowinadi

216

\section{PEMIKIRANDARIPERSPEKTIFTEOLOGIS}

Allah Tritunggal: Allah yang Bersahabat

Kristoforus Bala

Jürgen Moltmann: Persahabatan Sebagai Antisipasi Kepenuhan Harapan

Antonius Denny Firmanto

Communicatio In Sacris: Berbagi Kasanah Rohani

I Ketut Gegel

Gereja sebagai Komunitas Persahabatan

Markus Situmorang

Kolegialitas: Suatu Bentuk Berkelanjutan Imam

Edison R.L. Tinambunan

351

\section{PEMIKIRANDARITEOLOGIPRAKTIS}

Merayakan Persahabatan yang Memerdekakan

Robertus Pius Manik 
Homo Homini Amicus:

Tanggungjawab Kultural Gereja dalam Zaman ini Raymundus Sudhiarsa

Sollicitudo Omnium Ecclesiarum:

Kepedulian dan Kerjasama Gerejawi untuk Tanah Misi dan di Tanah Misi A. Tjatur Raharso ........................................................................ 408

Pengaruh Persahabatan Terhadap Kesejahteraan Hidup Manusia

Kurniawan Dwi Madyo Utomo

Persahabatan Sejati dalam Islam

Peter Bruno Sarbini

Misi dalam Kaitannya dengan Pemikiran Martin Buber/

Frans Hardjosetiko 466

Biodata Kontributor 


\title{
MERAYAKAN PERSAHABATAN \\ YANG MEMERDEKAKAN \\ Refleksi atas Pandangan Odo Casel Tentang Misteri \\ Kehadiran Karya Keselamatan dalam Liturgi
}

Robertus Pius Manik

\begin{abstract}
Scripture shows that liturgy is the basic reason why GOD saved his people so that God's chosen people might freely worship God (Ex 4:23) in spirit and truth'(Jn 4:24). Liturgy becomes a mediator and a moment for the real presence of God's saving deed. The relationship between God and His/Her people is drawn into a reality in our liturgy. Odo Casel reflects on our relationship with God is not a mere speculative idea but it is an objective reality that happens in our daily life. The Encyclic Mediator Dei emphasizes the Divine aspect of God's grace in the history of salvation that restored our relationship with God.
\end{abstract}

Keywords: Odo Casel, neo-scholastic, mystery, Mediator Dei, friendship, presence, liturgy.

\begin{abstract}
Abstrak
Kitab Suci Perjanjian Lama dan Perjanjian Baru menunjukkan bahwa salah satu alasan mengapa Allah membebaskan manusia ialah alasan liturgis, yakni supaya orang-orang pilihanNya beribadah kepadaNya dengan bebas (Kel 4:23) dalam roh dan kebenaran (Yoh 4:24). Liturgi menjadi mediator dan sekaligus menjadi momen di mana Allah dan karya keselamatanNya sungguh hadir secara nyata. Dalam liturgi, persahabatan antara Allah dengan manusia sungguh terjadi secara nyata. Odo Casel membantu kita untuk melihat persahabatan kita dengan Tuhan dalam liturgi bukan sebatas ide yang sifatnya spekulatif melainkan sebuah relasi mendalam yang secara obyektif
\end{abstract}


nyata dalam hidup sehari-hari. Mediator Dei menegaskan kembali aspek rahmat dari Allah berperan sangat kuat dalam menghadirkan karya keselamatan dari Allah sehingga relasi persahabatan Allah dengan manusia menjadi pulih.

Kata kunci: Odo Casel, neo-scholastic, misteri, Mediator Dei, persahabatan, kehadiran, liturgi.

\section{Perjanjian Lama: Panggilan untuk beribadah}

Alasan utama Allah mengadakan perjanjian dengan Bangsa Israel di kaki Gunung Sinai ialah agar bangsa Israel bisa beribadah (worship) kepada Allah dengan bebas. ${ }^{1}$ Worship di sini maksudnya ialah menyembah dalam konteks ibadat (liturgi) dengan doa, pujian, syukur. Persahabatan Allah dengan Israel adalah persahabatan dalam konteks liturgi dan sebaliknya liturgi bisa dirayakan dengan 'bebas' karena ada persahabatan dengan Allah. Liturgi adalah sebuah persahabatan Allah dengan Israel. ${ }^{2}$ Dengan kata lain, liturgi merupakan alasan penting mengapa Allah memanggil bangsa Israel keluar dari Mesir. ${ }^{3}$

Maka engkau harus berkata kepada Firaun: Beginilah firman TUHAN: Israel ialah anak-Ku, anak-Ku yang sulung; sebab itu Aku berfirman kepadamu: Biarkanlah anak-Ku itu pergi, supaya ia beribadah kepada$\mathbf{K u}$; tetapi jika engkau menolak membiarkannya pergi, maka Aku akan membunuh anakmu, anakmu yang sulung." (Kel 4:22-23).

Kisah ini mengindikasikan bahwa ketika bangsa Israel menyandang status budak, mereka tidak bisa beribadah kepada Tuhan dengan semestinya. Selain itu, relasi yang baik dan benar dengan Allah menjadi kunci bagi ibadah (liturgi) yang benar. Inisiatif terjalinnya relasi antara Allah dengan manusia (bangsa Israel) datang dari Allah dan manusia diminta untuk menanggapi

1 Brant Pitre, Jesus and the Jewish Roots of the Eucharist (NY: Doubleday, 2011), 28.

2 John Salza, The Biblical Basis for the Eucharist (Huntington, IN: 2008), 33-35.

3 Pitre, Jesus and the Jewish Roots of the Eucharist, 28. 
inisiatif dari Allah itu dan tanggapan manusia ditunjukkan dalam bentuk ritual (liturgi). ${ }^{4}$ Kisah Keluaran inimenunjukkan bahwa yang menjadi menjadi faktor penentu benar tidaknya suatu liturgi tidak diletakkan pada akurasi pelaksanaan peraturan ritual melainkan terjalinnya relasi persahabatan antara Allah dan manusia. Bila ikatan relasi persahabatan Allah dan manusia terganggu maka ritual liturgi menjadi kehilangan maknanya. Hal itu terlihat dari kisah bangsa Israel di kaki Gunung Sinai, ketika hati bangsa Israel tidak terarah kepada Allah tetapi kepada 'allah' lain maka relasi mereka dengan Tuhan rusak dan dengan sendirinya ibadah mereka menjadi berhala (Kel 32).

Ketika bangsa itu melihat, bahwa Musa mengundur-undurkan turun dari gunung itu, maka berkumpullah mereka mengerumuni Harun dan berkata kepadanya: "Mari, buatlah untuk kami allah, yang akan berjalan di depan kami sebab Musa ini, orang yang telah memimpin kami keluar dari tanah Mesir — kami tidak tahu apa yang telah terjadi dengan dia." Lalu berkatalah Harun kepada mereka: "Tanggalkanlah anting-anting emas yang ada pada telinga isterimu, anakmu laki-laki dan perempuan, dan bawalah semuanya kepadaku." Lalu seluruh bangsa itu menanggalkan anting-anting emas yang ada pada telinga mereka dan membawanya kepada Harun. Diterimanyalah itu dari tangan mereka, dibentuknya dengan pahat, dan dibuatnyalah dari padanya anak lembu tuangan. Kemudian berkatalah mereka: "Hai Israel, inilah Allahmu, yang telah menuntun engkau keluar dari tanah Mesir!" Ketika Harun melihat itu, didirikannyalah mezbah di depan anak lembu itu. Berserulah Harun, katanya: "Besok hari raya bagi TUHAN!" Dan keesokan harinya pagi-pagi maka mereka mempersembahkan korban bakaran dan korban keselamatan, sesudah itu duduklah bangsa itu untuk makan dan minum; kemudian bangunlah mereka dan bersukaria. (Kel 32:1-6).

Ketika bangsa Israel merasa Tuhan tidak hadir di tengah mereka, juga Musa orang pilihanNya juga tidak ada di tengah-tengah mereka, maka bangsa Israel itu beralih kepada "allah" ciptaan tangan mereka sendiri, dan dengan ritual liturgi mereka menghadirkan "allah" untuk mereka meskipun pada saat yang sama mereka mengingkari dan merusak relasi persahabatan

4 Ibid, 29-30. 
dengan Allah yang sesungguhnya. Ibadah (Liturgi) juga ternyata bisa menjadi 'pemicu' rusaknya relasi dengan Tuhan dan itu disebabkan oleh hilangnya kesadaran akan kehadiran Tuhan. Hasrat untuk memuja 'allah' yang sesuai dengan apa yang dipikirkan manusia bisa menjebak manusia dalam berhala. Atau, bisa juga terjadi di mana manusia (Gereja) hanya mau menerima ritual yang sesuai dengan kosep pikiran manusia saja lalu mengabaikan tujuan sejati dari ritual itu sendiri yakni Allah. Panggilan untuk melaksanakan ritual liturgi ternyata selalu mengandaikan adanya kesadaran akan kehadiran Tuhan yang membebaskan. ${ }^{5}$

\section{Perjanjian Baru: Persahabatan yang mengubah dan me- merdekakan}

Dalam Injil Yohanes (Yoh 4:1-42) dikisahkan dialog antara Yesus dengan seorang perempuan Samaria di bawah bayang-bayang tradisi konflik antara orang Yahudi dengan orang Samaria. Dikatakan bahwa orang Yahudi tidak bersahabat dengan orang Samaria, 'Sebab orang Yahudi tidak bergaul dengan orang Samaria' (Yoh 4:9). ${ }^{6}$ Yesus mendobrak tradisi negatif ini dengan mengambil inisiatif untuk membuka relasi dengan perempuan Samaria dengan membuka dialog meminta agar Dia diberi air. Suatu hal yang tidak lazim ketika Yesus seorang pria Yahudi meminta tolong kepada seorang perempuan Samaria yang baru saja bertemu di sumur. Yesus melanggar sebuah hukum tak tertulis tentang permusuhan orang Yahudi versus Orang Samaria sehingga dialog yang demikian itu dianggap tabu pada zaman itu. Namun, sepertinya bagi Yesus rasa haus akan persahabatan yang benar dalam iman jauh lebih penting daripada mempertahankan sebuah tradisi negatif yang mengekang. ${ }^{7}$ Sejarah konflik orang Yahudi dan orang

5 Ruth Langer, "The Presence of God in Jewish Liturgy" in The Spirit in Worship - Worship in the Spirit, eds. by Teresa Berger and Bryan D. Spinks (Collegeville, MN: Liturgical Press, 2009), 25-39, at 25.

6 Francis J. Moloney, The Gospel of John, vol. 4 of Sacra Pagina, ed. by Daniel J Harrington (Collegeville, MN, Liturgical Press, 1998), 117.

7 Benedict XVI, The Joy of Knowing Christ: Meditating on the Gospel (Frederick, Meryland: The Word Among Us, 2009), 63. Francis J Moloney, The Gospel of John, 117. 
Samaria bukan hanya dilatarbelakangi oleh alasan politik tetapi juga melibatkan alasan teologis termasuk juga soal ritual ibadat (liturgi). Dalam dialog itu, terjadi juga diskusi tentang liturgi antara Yesus dan perempuan Samaria, yakni tentang mana ibadah yang benar. ${ }^{8}$

Nenek moyang kami menyembah di atas gunung ini, tetapi kamu katakan, bahwa Yerusalemlah tempat orang menyembah." Kata Yesus kepadanya: "Percayalah kepada-Ku, hai perempuan, saatnya akan tiba, bahwa kamu akan menyembah Bapa bukan di gunung ini dan bukan juga di Yerusalem. Kamu menyembah apa yang tidak kamu kenal, kami menyembah apa yang kami kenal, sebab keselamatan datang dari bangsa Yahudi. Tetapi saatnya akan datang dan sudah tiba sekarang, bahwa penyembahpenyembah benar akan menyembah Bapa dalam roh dan kebenaran; sebab Bapa menghendaki penyembah-penyembah demikian. Allah itu Roh dan barangsiapa menyembah Dia, harus menyembah-Nya dalam roh dan kebenaran." (Yoh 4:20-24). ${ }^{9}$

Ironis bila sampai terjadi di mana ritual ibadah (liturgi) justru menciptakan jarak persahabatan antara manusia dengan Tuhan dan atara manusia (umat) dengan sesamanya. Itu sebabnya Yesus mengoreksi ibadah yang demikian. Melalui percakapanNya dengan perempuan Samaria terlihat issu liturgi juta ternyata termasuk pemicu konflik persahabatan antara orang Yahudi dan orang Samaria, bahkan antara manusia dengan Tuhan.

\section{Odo Casel: Teologi Misteri}

Diskusi (lebih tepatnya perdebatan) tentang teologi kehadiran Kristus dan karya keselamatanNya dalam sakramen masih menjadi perdebatan serius pada awal abad ke 20. Odo Casel, seorang Benediktin yang menaruh perhatian kepada liturgi secara khusus dalam kaitannya dengan sejarah dan tradisi gereja, berbicara tentang teologi "misteri" (mysterium) untuk menjelaskan makna kehadiran karya keselamatan Kristus dalam sakramen

8 Francis J Moloney, The Gospel of John, 118, 126.

9 Ibid., 132,133. 
khususnya dalam liturgi. ${ }^{10}$ Casel seakan sedang memprovokasi para teolog katolik pada zamannya untuk mencarai pendasaran teologi sistematis untuk memahami makna kehadiran karya keselamatan Kristus untuk konteks dunia pada saat itu. Casel mengatakan bahwa kehadiran karya keselamatan Kristus terjadi dalam 'misteri'. Terminologi 'misteri' yang digunakan Casel dalam teologinya diambil dari kata Yunani "mysterion" yang diterjemahkan dalam Bahasa Latin dengan kata "sacramentum". ${ }^{11}$ Kata 'misteri' yang digunakan oleh Casel dalam teologinya berbeda dengan makna kata misteri seperti kita pahami saat ini di mana kata misteri biasanya kita pahami bila sesuatu tidak kita ketahui atau tidak jelas untuk kita. Sebaliknya kata 'misteri' dalam teologi Casel ialah Allah yang transenden ('tidak kita ketahui dan tak terpahami') ternyata bisa kita lihat, bisa kita rasakan dan kita alami dan itu terjadi karena peristiwa inkarnasi. ${ }^{12}$ "Misteri" dalam teologi Casel merupakan peristiwa di mana Allah yang tidak kelihatan ternyata bisa hadir dan kita lihat dalam GerejaNya yang sedang merayakan iman. Oleh karena itu, menurut Casel, karya keselamatan Kristus sungguh hadir secara nyata, obyektif dan historis dalam sakramen dan bukan sekedar hadir dalam bentuk efek dari rahmat keselamatan yang pernah dilakukan Yesus dalam sejarah. ${ }^{13}$

\section{Neo-scholastic: causa-effectus}

Pandangan Casel ditolak oleh para teolog neo-scholastic (umumnya di Universitas Gregoriana) yang menganut paham bahwa kehadiran karya keselamatan Kristus dalam sakramen tidak mungkin hadir secara obyektif - historis melainkan hadir karena 'efek' rahmat yang dibawa secara sempurna oleh Yesus. Para pemikir neo-scholastic berpegang teguh pada teori 'causalitas' (Thomas Aquinas/Aristoteles) dan tidak menerima pandangan Casel karena mereka menyimpulkan bahwa bila karya

10 Odo Casel, The Mystery of Christian Worship, trans. by Burkhard Neunheuser, (London: Longman and Todd, 1960), 27.

11 Ibid.

12 Ibid.

13 Edward J. Kilmartin, The Eucharist in the West: History and Theology, ed. by Robert J. Daly (Collegeville, MN: Liturgical ress, 1998), 268-270. 
keselamatan Kristus itu hadir secara obyektif dan historis dalam liturgi itu artinya terjadi pengulangan kembali peristiwa Golgota, sengsara, wafat dan kebangkitan Kristus. ${ }^{14}$ Menurut pandangan kelompok neo-scholastic tindakan karya keselamatan yang dibawa oleh Yesus melalui peristiwa Golgota, sengsara, wafat dan kebangkitanNya terjadi satu kali dan tidak mungkin terulang kembali secara historis dalam liturgi, namun karya keselamatan Kristus itu sungguh membawa keselamatan sempurna dan effect rahmat yang diakibatkannya pun hadir secara sempurna dalam sakramen. ${ }^{15}$ Suatu peristiwa sejarah tidak mungkin bisa terjadi dua kali atau lebih secara obyektif, bahkan oleh pribadi yang Ilahi sekalipun dan satu peristiwa masa lampau tidak mungkin bisa terjadi dan ditarik ke masa kini. Peristiwa kurban salib terjadi hanya satu kali, tidak mungkin secara obyektif peristiwa 2000 tahun lalu bisa terjadi, ada dan hadir kembali pada saat ini. Yang terjadi pada perayaan Ekaristi adalah kehadiran peristiwa kurban Kristus dalam 'efek' atau 'akibat' (causa-effectus) dari rahmat. ${ }^{16}$

\section{Mediator Dei}

Perdebatan pandangan Casel dan kelompok neo-scholastic saat itu memang tidak menemukan titik temu secara tuntas namun telah mengangkat issu tentang kehadiran Kristus dalam sakramen ke level diskusi teologi yang serius. Bahkan, Paus Pius XII pun merespon diskusi teologis yang menjadi hangat itu saat mengeluarkan ensiklik Mediator Dei (1947). Mediator Dei sendiri memang tidak secara eksplisit menolak pandangan mengenai misteri kehadiran karya keselamatan Kristus secara nyata, obyektif dan historis yang dianut Casel namun ensiklik tersebut lebih condong menganut dan menekankan bahwa kehadiran karya keselamatan Kristus adalah kehadiran secara sempurna sebagai dampak (effect) dari tindakan karya keselamatan Yesus yang telah Dia lakukan dalam sejarah satu kali dan berdampak untuk semua generasi. ${ }^{17}$ Ensiklik Mediator Dei memang setia kepada pandangan

14 Ibid., 284-287.

15 Ibid., 255.

16 Ibid. 272.

17 Mediator Dei, 165.Kilmartin, The Eucharist in the West,188. 
neo-scholastic yang berpendapat bahwa dampak (effect) dari karya keselamatan itu jugalah yang membuat karya keselamatanNya bisa hadir secara sempurna dalam sakramen, ${ }^{18}$ namun di sisi lain ensiklik ini juga menerima pandangan Casel mengenai kehadiran aktif karya keselamatan Kristus dalam tindakan (action) liturgis. ${ }^{19}$ Bila Mediator Dei mengakui bahwa karya keselamatan Kristus secara aktif hadir dalam tindakan liturgis maka itu artinya secara tidak langsung mengakui misteri kehadiran karya keselamatan secara obyektif dan historis seperti yang dipahami Casel, tidak sekedar kehadiran akibat effect dari karya keselamatan yang dulu pernah dilakukan Yesus satu kali dalam sejarah hidupNya. ${ }^{20}$

Memang dokumen Mediator Dei dikeluarkan oleh Paus Pius XII bukan pertama-tama untuk menanggapi pandangan Casel yang menjadi hangat pada saat itu, dan juga bukan untuk menghentikan perdebatan sengi tantara Casel dan kelompok neo-scholastic, namun Mediator Dei sedang melibatkan diri masuk dalam dinamika perkembangan refleksi teologis tentang sakramen dan liturgi khususnya berkaitan dengan makna kehadiran karya keselamatan Kristus dalam Gereja. Semuanya ini merupakan perjalanan refleksi Gereja mengenai relasi atau persahabatan Gereja dengan Tuhan. Mediator Dei menegaskan bahwa perayaan iman (liturgi) perayaan kehadiran Allah dan karya keselamatanNya bagi manusia karena Allah ingin membawa manusia masuk ke dalama relasi persahabatan yang kekal di mana Tuhan tidak mau meninggalkan manusia seperti yatim-piatu. ${ }^{21}$

\section{Pasca Konsili Vatikan II}

Ensiklik Mediator Dei yang dikeluarkan oleh Paus Pius XII (1947) memberi pengaruh yang sangat besar untuk teologi liturgi saat ini teristimewa karena muatan teologis dokumen ini sangat mewarnai dokumen Sacrosanctum Concilium. Casel berhasil membawa refleksi 'baru' dalam

18 Mediator Dei,20, 21.

19 Mediator Dei, 165.

20 Mediator Dei, 151

21 Mediator Dei, 18. 
liturgi tentang makna kehadiran karya keselamatan Kristus bagi dunia, dengan mengangkat isu teologi "kehadiran karya keselamatan" dari level spekulatif dan ide masuk ke level "historis" dan "obyektif". Persahabatan manusia (Gereja) dengan Tuhan dan dengan sesama tidak cukup hanya sebatas ide dan spekulasi melainkan harus menyentuh tataran konkret. Liturgi yang kita rayakan adalah perayaan iman yang konkret bukan iman dalam tataran ide dan spekulasi. Mediator Dei bahkan dengan cukup yakin menyatakan tentang kehadiran nyata Kristus dalam perayaan liturgi dalam diri imam pelayan altarNya, dalam rupa Sakramen Maha Kudus (Roti danAnggur yang telah menjadi Tubuh dan DarahNya), hadir dalam doa yang kita panjatkan. ${ }^{22}$ Di kemudian hari, Sacrosanctum Cocilium juga mengulangi lagi pernyataan itu: “...Ia hadir dalam Kurban Misa, baik dalam pribadi pelayan, "karena yang sekarang mempersembahkan diri melalui pelayanan imam sama saja dengan Dia yang ketika itu mengorbankan Diri di kayu salib, maupun terutama dalam (kedua) rupa Ekaristi. ..." (SC 7).

Casel tidak pernah mengatakan terjadi pengulangan misteri kurban kristus. Casel bahkan menekankan bahwa kurban Yesus itu hanya terjadi satu kali untuk selama-lamanya. ${ }^{23}$ Kehadiran Yesus itu adalah kehadiran dalam konteks mysterion yakni kehadiranNya secara sakramental. Yesus hadir bukan hanya sekedar efek atau akibat dari Rahmat, tetapi Yesus sungguh obyektif hadir, dan karena kekuatan Roh Kudus, kita yang merayakan Ekaristi di bawa masuk dalam peristiwa kurban yang sekali dan untuk selama-lamanya. Casel mengatakan, berkat Roh Kudus, kehadiran obyektif kurban Kristus sungguh terjadi. Roh Kudus mampu membongkar sekat/batas waktu/sejarah yang terbatas dan membawa semua orang yang merayakan Ekaristi masuk dan hadir dalam karya keselamatan secara obyektif.

Dari kelompok neo-scholastic dan Casel, Gereja saat ini (pasca Konsili Vatikan II) bergerak lebih jauh lagi dengan pembaharuan liturgi yakni di satu sisi tetap menjaga keberlangsungan tradisi suci Gereja dalam tata

22 Mediator Dei, 20.

23 Casel, The Mystery of Christian Worship, 104. 
perayaan ibadat dan di sisi lain ibadat (Liturgi) itu sendiri harus menjangkau kehidupan kongkrit umat, di mana dampak (effect)dari kehadiran keselamatan dalam liturgi harus nyata (obyektif) dirasakan oleh umat (Gereja). Persahabatan antara Allah dan manusia (Gereja) yang dirayakan dalam liturgi harus nyata (obyektif) dalam kehidupan kongkrit. Konsekwensi lebih lanjut dari perkembangan pandangan teologis pasca Konsili Vatikan II ini memang masih menjadi polemik tersendiri. Interpretasi terhadap makna kehadiran karya keselamatan secara obyektif bisa saja dipahami menjadi sangat materialistis, psikologis, bahkan sampai menjadi sangat ekonomis dan politis, misalnya terlihat dari dinamika perkembangan teologi pembebasan pada saat ini.

\section{Penutup}

Relasi (persahabatan) kita dengan Tuhan terganggu ketika kita masih melekat dengan dosa, dan itu artinya ketika kita masih menjadi "budak" dosa maka kita juga tidak bisa beribadah secara semestinya. Kisah Perjanjian Lama ini kemudian menjadi peringatan bagi Gereja bahwa ibadah (Liturgi) selalu memanggil umat (Gereja itu sendiri) untuk terus bertobat sehingga dapat beribadah dengan semestinya. Liturgi memanggil kita untuk terus menjaga relasi persahabatan dengan Allah. Persahabatan antara Allah dan bangsa Israel yang terwujud dalam ibadat telah mengubah hidup dan status bangsa Israel dari budak menjadi orang pilihan Allah, sama seperti persahabatan Yesus dengan perempuan Samaria telah mengubahnya dari manusia lama menjadi manusia baru yang akan beribadah kepada Allah dalam roh dan kebenaran. Persahabatan dengan Allah selalu membawa perubahan yang konstruktif. Liturgi yang baik dan benar itu juga harus menggerakkan umat beriman untuk berubah menjadi semakin baik dan benar hingga pada tataran hidup kongkrit.

Panggilan merayakan liturgi terus menerus adalah sebuah panggilan untuk merawat persahabatan dan memperdalam relasi hingga ke level relasi persahabatan yang paling tinggi. Liturgi menjadi seperti sebuah sekolah kehidupan di mana Allah sendiri hadir sebagai sahabat atau bahkan sebagai saudara yang mengubah kita menjadi semakin manusiawi dan bermartabat. 
Dalam liturgi Allah dan umat (Gereja) hadir dalam ikatan relasi persahabatan yang kuat satu sama lain yang dilandasi oleh kasih. Dengan kehadiran yang dilandasi kasih ini maka liturgi pun selalu merupakan tindakan komunitas (jemaat/Gereja) dan tidak pernah menjadi tindakan individual. Komunitas tidak mungkin terbangun tanpa relasi persahabatan, dan persahabatan selalu mengandaikan kasih, dan kasih yang terbesar menurut Yesus terungkap dalam kurban.

Liturgi (Ibadah) selalu memanggil kita untuk masuk dalam sebuah relasi yang mendalam baik dengan Tuhan maupun dengan sesama. Liturgi yang mengabaikan relasi (persahabatan) bukanlah liturgi. Liturgi yang tidak mengandaikan persahabatan adalah suatu hal yang tak terbayangkan. Liturgi adalah perayaan iman Gereja dan Gereja dengan sendirinya mengandaikan relasi atau persahabatan (persaudaraan) dengan Tuhan dan persahabatan (persaudaraan) di antara anggotanya. Persahabatan sejati itu membebaskan dan tidak melanggengkan perbudakan dosa, seperti persahabatan Allah dengan bangsa Israel adalah persahabatan yang membebaskan dari perbudakan. Merayakan ibadat (liturgi) adalah perayaan persahabatan yang menyembuhkan dan membebaskan dari perbudakan dosa.

Persahabatan itu selalu mengandaikan kesadaran akan diri sendiri dan orang lain. Karl Rahner mengatakan bahwa kesadaran diri dan pengenalan diri sendiri merupakan buah dari kesadaran akan kehadiran orang lain, serta keterbukaan hati untuk berbagi dalam pengetahuan dan kasih dengan orang lain akan menghasilkan kepenuhan hidup. ${ }^{24}$ Kesadaran diri dan keterbukaan hati untuk berbagi selalu diekspresikan melalui simbol. ${ }^{25}$ Kristus juga menggunakan simbol saat mengekspresikan diriNya dan kasihNya, dan ekspresi itulah yang dirayakan Gereja dengan menggunakan simbol dan ritual (liturgi) sebagai buah dari kesadaran Gereja akan kehadiran Tuhan dan karya keselamatanNya.

24 Karl Rahner, More Recent Writings, vol. IV of Theological Investigation, trans. by Kevin Smith (London: Darton, Longman and Todd, 1966), 229.

25 Ibid., 224. 


\section{KEPUSTAKAAN}

Benedict XVI.The Joy of Knowing Christ: Meditating on the Gospel. Frederick, Maryland: The Word Among Us, 2009.

Berger, Teresa and Bryan D. Spinks, eds.The Spirit in Worship - Worship in the Spirit. Collegeville, MN: Liturgical Press, 2009.

Casel, Odo. The Mystery of Christian Worship.Translated by Burkhard Neunheuser. London: Longman and Todd, 1960.

Kilmartin, Edward J. The Eucharist in the West, History and Theology. Edited by Robert J. Daly. Collegeville, MN: Liturgical Press, 1998.

Langer, Ruth. Jewish Liturgy: A Guide to Research. Lanham, MD: 2015. Léon-Dufour, Xavier. Dictionary of the New Testament. Translated by Terrence Prendergast. London: Geoffrey Chapman, 1980.

Moloney,Francis J. The Gospel of John.Vol. 4 of Sacra Pagina.Edited by Daniel J Harrington. Collegeville, MN, Liturgical Press, 1998.

Pitre, Brant.Jesus and the Jewish Roots of the Eucharist. NY: Doubleday, 2011.

Rahner, Karl. More Recent Writings. Vol. IV of Theological Investigation. Translated by Kevin Smith. London: Darton, Longman and Todd, 1966.

Salza, John. The Biblical Basis for the Eucharist. Huntington, IN: Our Sunday Visitor, 2008. 